\title{
The Use of Story Calendar Media to Increase Reading Comprehension Skill in Elementary School
}

\author{
Krisna Anggraeni \\ Majalengka University, Majalengka, Indonesia \\ krisnaanggraeni24@gmail.com
}

\begin{abstract}
This research was motivated by the low reading comprehension skill in elementary school. The result of students' learning mastery in $5^{\text {th }}$ grade of SDN Sunia 1 reached only $20 \%$ with the 65 score in the KKM of Bahasa. The problem encouraged the researcher and the classroom teacher to work on improving reading comprehension skill using story calendar media. Story calendar media presents the material in the form of calendars that relates to each other so that it can be used as a portfolio. Each calendar page illustrates the development of student literacy and it is also complemented by graphic organizers which are some visual graphs that show the relationship between ideas, concepts, facts and terms in a single topic. This research used a classroom action research that was designed to empower all participants in the process (students, teachers and other participants) which was meant for improving the process and student learning results. The design used in this research was Classroom Action Eesearch Elliot design. This research was conducted in 3 cycles. Each cycle consisted of planning, implementation, observation, and reflection steps. The result of the research shows that story calendar media can improve reading comprehension skill. Based on the result of the reading comprehension test, it is known that the average of test results has increased. In the pre cycle, the reading comprehension was only $20 \%$, in the cycle I it increased into $40 \%$, in the cycle II it increased into $75 \%$ and in the cycle III it increased into $90 \%$. These improvements show that story calendar media helps the students learn to improve their reading comprehension skills.
\end{abstract}

Keyword: story calendar media, reading comprehension skill

\section{INTRODUCTION}

Reading is one of four language skills: listening, speaking, reading and writing. Permendikbud (regulation of Ministry of Education and Culture) Number 57 Year 2014 attachment III on Integrated Thematic Learning of Low Grade contains a statement about reading which not only plays a role in improving the language skills of children. But, it further provides benefits for the development of thinking skill that will support increasing comprehension on other subjects. Hodgson suggests that reading is a process done and used by the reader to obtain a message, which would be conveyed by the author through the media of words or written language (Tarigan, 2013). Based on that case, reading comprehension becomes an important skill possessed as a form of fluency in language.

The importance of reading comprehension is not yet supported by the success in learning to read. In 2013-2014 USAID Amerika Ed Data II, RTI International made the cooperation with the Ministry of Education and Culture (Kemendikbud), Ministry of Religious Affairs (MORA/Kemenag) and Myriad Research that had assessed early grade students' reading skill (Egra) and Portrait of School Management Effectiveness (SSME) in Indonesia. The research was conducted on 4,800 elementary students $2^{\text {nd }}$ grade in $400 \mathrm{SD} / \mathrm{MI}$ in four regions of Sumatra, Java, Bali, Kalimantan-Sulawesi-Nusa Tenggara and MalukuPapua (MNP). The survey result showed that only 48 percent of elementary school students who could read fluently and understand what they read. While the 5.9 percent of all students in $2^{\text {nd }}$ grade in Indonesia were categorized as low (could not read).

The problems in the process and the results of reading comprehension skill are also found in $5^{\text {th }}$ grade of SDN Sunia 1. Based on the pre-cycle observation held on Monday, February 13, 2017, the researcher found that the learning strategies in reading comprehension commonly used by the teachers was giving reading assignments that were followed by answering questions related to the reading. The precycle test results showed the students' reading comprehension skill was still low. In the pre-cycle test, it showed that only $20 \%$ of students who passed the KKM of 65 , while $80 \%$ of students were still failed.

This was due to some problems in learning to read, among which were: (1) Bahasa was considered as a boring lesson; (2) the teaching of Bahasa was only monotonous and had less variation; and (3) the teaching of Bahasa was more formal and to pursue the material from the package book. The absence of high enthusiasm has made Bahasa less important than other subjects. The students' interests concerning both the interest in reading and the interest in following the subject of Bahasa seemed to be decreased.

In order to improve the reading comprehension, it is necessary to do the learning corrective action. The researcher chose the corrective action using story calendar media to improve reading comprehension skill. The story calendar is an arrangement of several sheets of paper that contains neat and well-ordered messages or learning materials that are created like a calendar, so that each page can be used for different days. A story calendar is a practical, effective, and efficient literacy media and it can be used as a learning tool for students, both inside and outside the classroom. The story calendar is one of the visual media in language learning. The characteristic of elementary school students is having a short concentration range that requires supporting media so that they are interested in learning. the use of visual media makes students more memorable the information than just using text media. In addition, the visual media can help develop ideas, imagination and creativity of students that will help students' understanding.

The main formulation of the problem in this research is can the story calendar media improve the reading comprehension in $5^{\text {th }}$ grade SDN Sunia 1 ? The 
main objective of this research is to determine the increase reading comprehension skills by using a story calendar media in $5^{\text {th }}$ grade SDN Sunia 1. Reading comprehension according to Resmini and Juanda (2007) is one form of reading activities with the primary purpose of understanding the content of messages contained in the text. Reading comprehension is more emphasized on the mastery of reading content, not on the beautiful, fast or slow reading.

According to McLaughlin \& Allen the principles of reading that affect reading comprehension are as follows: (1) understanding is the process of social construction; (2) the balance of the script mastery (kemahiraksaraan) is a curriculum framework that fosters understanding; (3) the teacher that reads professionally (superior) affects the students learning; (4) a good reader plays a strategic and active role in the process of reading; (5) reading should occur in a meaningful context; (6) students discover the benefits of reading derived from various texts at various levels of the grade; (7) vocabulary development and learning affect reading comprehension; (8) inclusion is a factor of understanding process; (9) strategies and reading skill can be taught, and (10) dynamic assessments inform reading comprehension learning (Rahim, 2008).

The indications of reading comprehension that must be achieved according to Brown are as follows: (1) perform, the reader responds physically to the reading command; (2) select, the reader chooses the oral attenuation of both oral and written comprehension; (3) divert, the reader is able to communicate verbally what he has read; (4) answer, the reader is able to answer questions about the content of the reading; (5) consider, the reader is able to underscore or record important messages contained in the reading; (6) expand, the reader is able to expand the reading or minimally able to compose the final part of the story (especially for fictional reading); (7) duplicate, the reader is able to create a discourse similar to the discourse he reads; (8) modeling, the reader is able to play the story he has read; and (9) change, the reader is able to change the discourse into another form of discourse indicating the existence of information processing (Abidin, 2012).

The indications of reading comprehension by Hartati (2015) can also be seen from the mastery of ADISIMBA (what, where, who, why, how). The questions in reading comprehension are three kinds; include lateral, inferent and creative questions. Lateral questions are questions that have an explicit answer in the discourse. The inferent questions are questions whose answer is implied in the discourse. Creative questions are questions that dig deeper the discourse and bring up new possibilities / ideas / opinions. The evaluation in reading comprehension is included in the all three questions. The role of teachers in reading comprehension is to help students understand, interpret, assess, and cultivate interest, attention, and a positive attitude to the texts and the values contained therein.

Wilson \& Scanlon (2011) say that readers also interact with the text they read, and the meaning they take from the texts will depend on several factors such as: the age of the readers, the readers' knowledge of what they read, their experience of the text content, their opinion of the writers and so on. For that teachers it needs to develop a learning media that supports students in interacting with the text they read. Some literacy media supports that includes images of series, big books, and story calendar media.

The story calendar is a practical, effective, and efficient literacy media and can be used as a learning tool for students, both inside and outside the graderoom. Story calendar is also easy to create by teachers. In the Lecture Book for LPTK Lecturers (2014) explained the story calendar is an arrangement of several sheets of paper containing neat and wellordered messages or learning materials that are created like calendars. It is called the story calendar because its shape is like a calendar. Each page can be used for different days.

The purpose of using story calendars are: (1) motivate students in reading and writing because each page has a linkage, and (2) facilitate the teacher in assessing the development of literacy skills for a certain period of time. The following is an example of a story calendar form. In the example of a story calendar, it consists of a calendar cover followed by seven supporting activities: (1) reading text (can be done by silent reading, interactive reading aloud or shared reading); (2) retelling by mentioning the background of the story; (3) describing and explaining the characters of the story; (4) writing articles based on the experience with themes / topics according to the story calendar; (5) writing down things to do if becoming one of the characters; (6) giving opinions of liked and disliked characters with reasons; and (7) doing the last activity by making poetry about the characters or the appropriate themes / topics.

The advantages of story calendars are: (1) enriched with images that help students explore and imagine; (2) the materials in the calendar are related each other so that they can be used as a portfolio for each page describes the development of students literacy; and (3) can be equipped with a graphic organizer (GO) which is a visual graph showing the relationship between ideas, concepts, facts, and terms in a single main topic. In making the story calendars there are several steps that teachers should do.

First, the teacher composes the calendar theme / topic, it should be appropriate with the indicators and learning objectives in the curriculum so that the focus of the story calendar is clear. For example, in learning reading comprehension, reading aloud, creative writing, etc. Second, teachers compiles the number of meetings and activity plans for each meeting of the story calendar. The number of meetings is also adjusted to the syllabus of the theme / topic. Third, teachers can prepare teaching materials such as text and pictures to be used in each meeting of story calendars. Fourth, teachers compile teaching materials into story calendars. The paper size and the type of paper used are free, but must pay attention to the ease of use by the students. The story calendar consists of a calendar cover, followed by an activity plan for each meeting. 
The story calendars are also in line with the activities to determine the students' appreciation of the content of the story according to Supriyadi (2006), which can be: (1) ask questions about the mandate of the story; (2) retell in their own language; (3) mention the background of the story; (4) summarize the story in written form; and (5) change the story in poetry, and so on. Thus, not only develop the writing skill, but

teachers can also see the extent of students' understanding of the story read. The researcher formulated the action hypotheses on the research i.e. if the story calendar media used in learning Bahasa, so the reading comprehension skill of students in $5^{\text {th }}$ grade SDN Sunia 1 Banjaran District of Majalengka academic year 2016/2017 would increase.
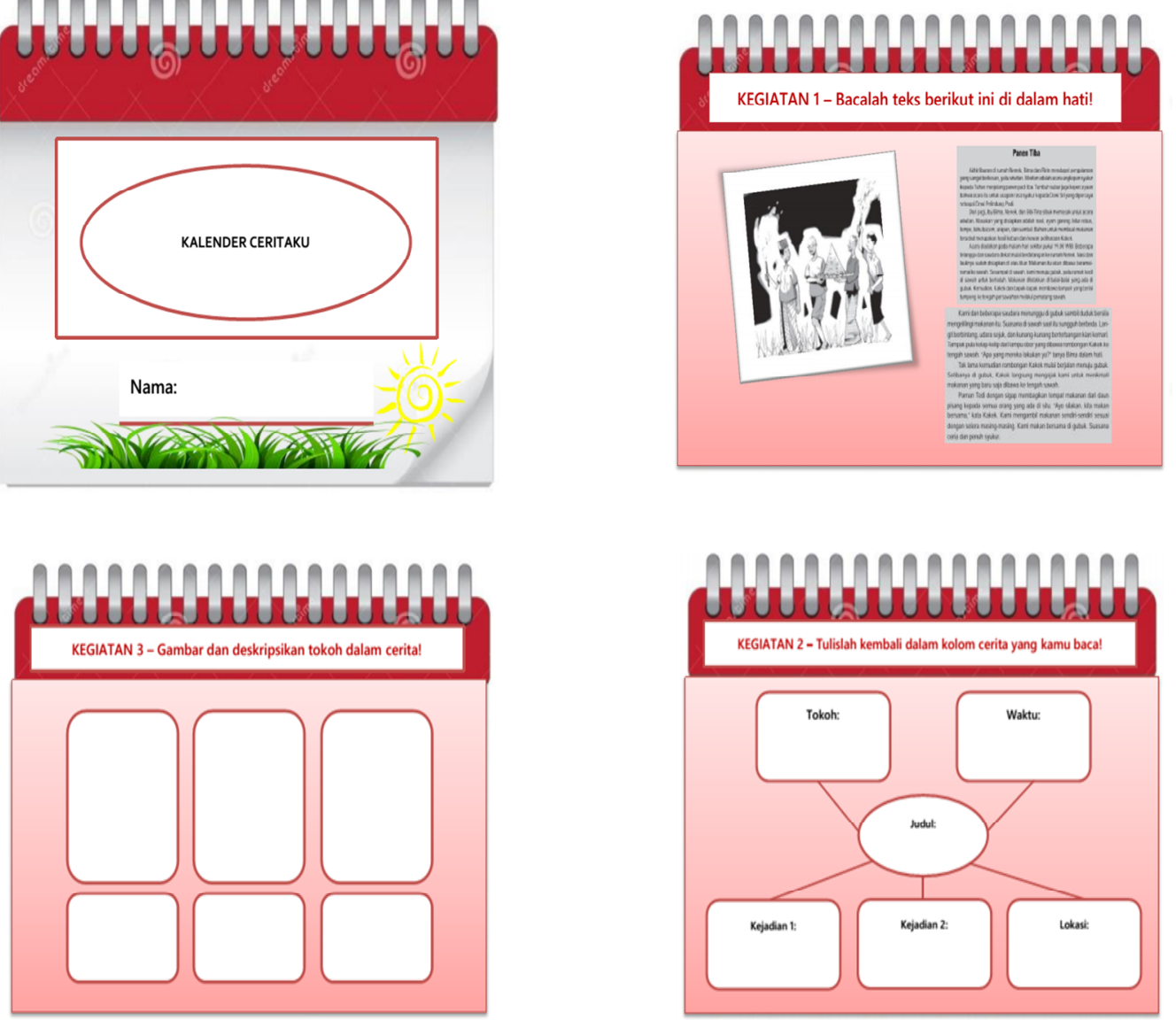

The Exemple of Story Calender Media (Adapted USAID, 2014)

\section{METHODS}

This research began in February 2017 to May 2017. The details of the research activities included: (1) the preparation of research; (2) the preparation coordination of corrective actions; (3) the implementation of corrective actions; and (4) preparation of the report. The research was conducted in SDN Sunia 1 Banjaran District of Majalengka academic year 2016/2017. The subjects were the students in $5^{\text {th }}$ grade SDN Sunia 1 of 20 students with 8 male students and 12 female students. The subjects selected based on the finding that there were the low skills of reading comprehension of students. The technique of data collecting consisted in the form of test that was the reading comprehension test, the observation guidelines were in the form of the teacher and students observation sheets, the interview guidelines were in the form of the teacher and students interview guidances, the field notes were in the form of field notes sheets and documentations.
This research used the Classroom Action Research that defined by Hopskin as a process designed to empower all participants in the process (students, teachers, and other participants) with a view to improve some practices organized in the experience of education (Emzir, 2008). Cresswell (2015) explains that action research provides a mean for teachers and educators in schools to improve the practices to take an action to continue participating in the research. In this research, the design of Classroom Action Research used was John Elliot design. In this design it was began with the discovery of the analysis. Furthermore, there was an improvement action consisted of 3 cycles. Each cycle consisted of four stages, namely preparation, implementation of actions, monitoring and reflection.

The validation in this research used the triangulation technique which defined by Komara and Anang (2016) as a technique of checking the truth of the data or information about the implementation of the action by confirming the data truth. For the data 
analysis it was consisted of two kinds, i.e. qualitative and quantitative data. The qualitative data was in the form of teacher and student observation sheets which were calculated by looking at the percentage and then they were categorized. While the quantitative data was in the form of reading comprehension test results that were seen individually and classically. The individual's reading comprehension skill was seen by comparing the average of each cycle. Furthermore, the average was compared to the Minimum Criteria of Completion (KKM) of 65. Meanwhile, the classical completeness explained by Mulyasa (2014) that 'class success is seen from the number of students who are able to reach at least $85 \%$ of the number of students in the class'. The learning achievement of this $85 \%$ was then used as an indicator of research success.

\section{RESULTS AND DISCUSSION}

This research was conducted in several stages. The first stage was pre-cycle held on Monday, February 13, 2017. The pre-cycle was conducted to determine students' reading comprehension skill and to observe how the learning process conducted by the class teacher. At this pre-cycle stage, the researcher also conducted an interview with the class teacher and the student representatives, in order to strengthen the data of the observation. Based on the results of precycle test, it was showed that from 20 students who had reached KKM of 65 was only 4 students or $20 \%$, while 16 other students or $80 \%$ still had not reached KKM 65. This pre-cycle result showed that the reading comprehension skills of students of 5th grade SDN Sunia 1 needed to be improved. The corrective action was done in 3 cycles each cycle consisted of 3 meetings. Each meeting consisted of 4 stages i.e. planning, implementation, monitoring, and reflection

The first meeting in cycle I was held on Tuesday, March 14, 2017. The second meeting was held on Thursday, March 16, 2017. The third meeting was held on Tuesday, March 21, 2017. In this cycle I of the researcher used the story calendar with the theme "lingkunganku" (my environment). The results of the reading comprehension test in cycle 1 had an increase from the pre-cycle. The average class was 64 . The number of students who passed was 8 students or $40 \%$, while 12 other students or $60 \%$ still failed. Based on the teacher observation sheet, the teacher's observation during the learning process reached $75 \%$ in both categories. Meanwhile, the student observation sheets obtained $70 \%$ in a good category. The research was continued in cycle II.

The first meeting in cycle II was held on Tuesday, March 28, 2017. The second meeting was on Thursday, March 30, 2017 and a third meeting was on Tuesday, April 4, 2017. In this second cycle the researcher used the story calendar with the theme "kebersamaan" (togetherness). The results of reading comprehension test in cycle II had increased from cycle I. The average class reached 69. the number of students who passed was 15 students or $75 \%$ and 5 other students or $40 \%$ of students still failed. The teacher observation sheet reached $86.66 \%$ in the excellent category while the student observation sheet reached
$83.33 \%$ in the excellent category. The research was continued in cycle III.

The first meeting in cycle III was held on Tuesday, April 11, 2017. The second meeting was on Thursday, April 13, 2017 and the third meeting was on Tuesday, April 18, 2017. In this third cycle the researcher used the story calendar with the theme "transportasi" (transportation). The average class in the cycle III reached 76 with students who passed were $90 \%$ or 18 students, while two other students, or $10 \%$ were failed. The teacher observation sheet reached $90 \%$ in excellent category while the student observation sheet reached $93.33 \%$ in excellent category. The action giving was stopped in the third cycle because the success indicator had reached $85 \%$.

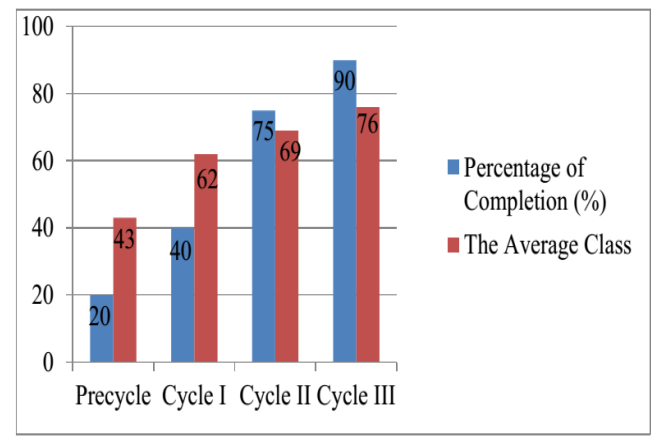

Picture 2

The Graph of Reading Comprehension

In the table and graphic, the increase in the reading comprehension test results from Pre-cycle to cycle III can be seen. The significant improvement occurred from cycle I to cycle II. This was because the students had already understood and been familiar with the learning process using the story calendar media. On reading comprehension learning by using a story calendar media, in the first step the students are asked to read a text related to the theme. The purpose of this activity is that students acquire some keywords that fit the theme. The discovery of some keywords according to Wycoff (2004) is very important to capture the mind quickly so that students can develop all the potential minds they have. It aims to enable students in developing a good memory, organize their thoughts, and improve their understanding.

The series of activities such as rewriting the story in the chart, explaining and describing the characters in the story, writing a supposition if becoming one of the characters, and giving the opinion on the liked or disliked figures to form an idea about the main mapping related to the theme. The mapping helps students understand the reading texts. In arranging a story calendar, teachers can create together with students, so that students can choose their favorite story. The selection of different stories can also be used by students to share the stories and show the activities in their calendars each other. Furthermore, the story calendar can also be arranged in a corner / reading corner or class library as part of the activity of developing a literary classroom environment. 


\section{CONCLUSION}

The reading comprehension skill using the story calendar media in $5^{\text {th }}$ grade SDN Sunia 1 students had increased. The percentage of pre-cycle completeness of $20 \%$ increased to $40 \%$ in the first cycle, to $75 \%$ in the second cycle and to $90 \%$ in the third cycle. This improvement indicates that the story calendar media is effectively used in learning to improve reading comprehension skills. The suggestion that the researcher can provide related to the results of this research is that teachers can use story calendar media as an alternative development of learning media to improve reading comprehension skill in elementary school.

\section{REFERENCES}

[1] Abidin, Y. 2012. Pembelajaran Membaca Berbasis Pendidikan Karakter. Bandung: Refika Aditama.

[2] Cresswell, J. W. 2012. Educational Research: Planning, Conducting, and Evaluating Quantitative and Qualitative Research. Boston: Pearson Education, Inc.

[3] Emzir. 2008. Metodelogi Penelitian Pendidikan. Jakarta : PT Rajagrafindo.

[4] Hartati, T. 2014. Efektivitas model membaca permulaan steinberg di sekolah dasar. Jurnal Pedagodik Pendidikan Dasar, 2(1), 82-96.

[5] Komara, and Anang, M. 2016. Pengembangan Keprofesian Berkelanjutan dan Penelitian Tindakan Kelas. Bandung: PT Refika Aditama.

[6] Rahim, F. 2008. Pengajaran Membaca di Sekolah Dasar. Jakarta: Bumi Aksara.

[7] Resmini, N \& Juanda, D. 2007. Pendidikan Bahasa dan Sastra Indonesia di Kelas Tinggi. Bandung: UPI Press.

[8] Supriyadi. 2006. Pembelajaran Sastra yang Apresiatif dan Integratif di Sekolah Dasar. Jakarta: Ministry of National Education.

[9] Tarigan, H. G. 2013. Membaca: Sebagai suatu ketrampilan berbahasa. Bandung: Angkasa.

[10] USAID. 2014. Buku Sumber untuk Dosen LPTK: Pembelajaran Literasi Kelas Awal LPTK. Bandung: USAID.

[11] Wilson, A., \& Scanlon, J. 2011. Language Knowledge for Primary Teachers. New York: Routledge

[12] Wycoff, J. 2004. Menjadi Super Kreatif Melalui Metode Pemetaan Pikiran. Jakarta: KAIFA. 